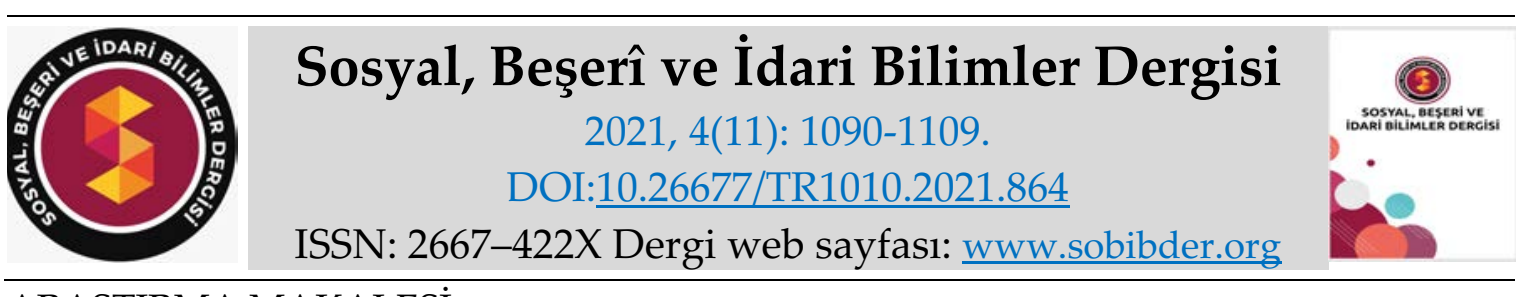

ARASTTIRMA MAKALESI

\title{
Otel İşletmeleri Çalışanlarında Etik Liderlik Algısı, Kariyerizm ve İşgören Performansı İlişkisi: İstanbul Örneği*
}

Elif DÜLGER, Yüksek Lisans Öğrencisi, İskenderun Teknik Üniversitesi, Lisansüstü Eğitim Enstitüsü, Hatay, e-posta: elifdulger88@gmail.com

ORCID: https://orcid.org/0000-0003-2996-528X

Dr. Öğr. Üyesi Hasan CINNIIOĞLU, İskenderun Teknik Üniversitesi, Turizm Fakültesi, Hatay, eposta: hasan.cinnioglu@iste.edu.tr

ORCID: https://orcid.org/0000-0001-7826-619X

\section{Öz}

$\mathrm{Bu}$ çalışmanın temel amacı, otel çalışanlarının yöneticilerinde algıladıkları etik liderlik davranışının kariyerizm ve performans düzeylerine etkisini ortaya koymaktır. Bu amaçla, basit tesadüfi örneklem tekniği ile seçilmiş 389 otel çalışanına anket yöntemi uygulanarak veri toplanmıştır. Araştırmanın evreni İstanbul ilinde hizmet vermekte olan konaklama işletmeleri oluşurken, örneklem ise yine bu bölgede bulunan beş yıldızlı otel çalışanlarıdır. Yapılan çalışma sonuçları, işgörenlerin performans ve etik liderlik algı düzeylerinin orta, kariyerizm algı düzeylerinin ise düşük seviyede olduğunu göstermektedir. Ayrıca, etik liderlik algısının kariyerizmi, kariyerizm algısının da işgören performansını negatif yönde etkilediği ortaya çıkmıştır. Bununla birlikte, etik liderlik algısının işgören performansı üzerinde pozitif yönde bir etkisi olduğu da çalışmanın sonuçlarından biridir. Otel işletmelerinde, etik kodlara önem veren, işgörenleri ile sağlıklı bir iletişim kuran ve karar alma sürecinde işgörenlerin de fikrini alan bir liderin olmasının, kariyerist yönelimin önüne geçebileceği öngörülebilir. Bir negatif örgütsel davranış olan kariyerizm yöneliminin önüne geçilmesi ile emeğin en önemli unsur olduğu otellerde, işgören performanslarının yükseleceği düşünülebilir.

* Bu makale 16-18 Ocak 2021 tarihinde İstanbul/Türkiye'de gerçekleştirilen " ${ }^{\text {th }}$ International Management and Social Research Conference" kongresinde özet bildiri olarak sunulmuştur.

Anahtar Kelimeler: Etik Liderlik, Kariyerizm, İşgören Performansı, Otel İşletmeleri.

Makale Gönderme Tarihi: 15.07.2021

Makale Kabul Tarihi: 01.11.2021

\section{Önerilen Atıf:}

Dülger, E. ve Cinnioğlu, H. (2021). Otel İşletmeleri Çalışanlarında Etik Liderlik Algısı, Kariyerizm ve İşgören Performansı İlişkisi: İstanbul Örneği, Sosyal, Beşeri ve İdari Bilimler Dergisi, 4(11): 10901109. 


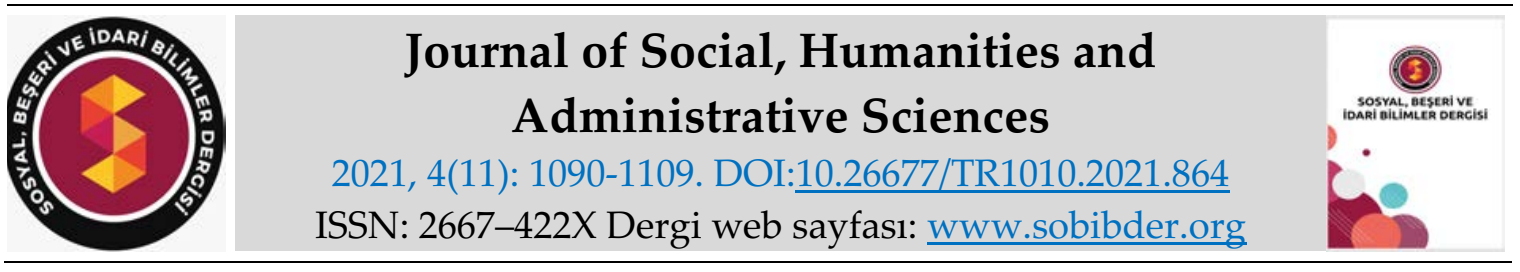

RESEARCH PAPER

\title{
The Relationship Between Perception of Ethical Leadership, Careerism and Employee Performance in Hotel Business Employees: The Case of İstanbul
}

Elif DÜLGER, MSc. Student, İskenderun Technical University, Graduate School of Education, Hatay, e-mail: elifdulger88@gmail.com ORCID: https://orcid.org/0000-0003-2996-528X

Assistant Prof. Dr. Hasan CINNNIOĞLU, İskenderun Technical University, Faculty of Tourism, Hatay, e-mail: hasan.cinnioglu@iste.edu.tr ORCID: https://orcid.org/0000-0001-7826-619X

\begin{abstract}
The main purpose of this study is examining the impact of hotel employees' perceptions of their managers' ethical leadership behavior on careerism and performance levels. For this purpose, dates were collected using the questionnaire method on 389 hotel employees who were chosen using a simple random sample methodology. While the study's universe is made up of accommodation establishments in Istanbul province, the sample is made up of staff of five-star hotels in the area. According to the study's findings, employees' perceptions of performance and ethical leadership are medium, while their perceptions of careerism are low. Furthermore, it has been discovered that ethical leadership perception has a negative impact on careerism, and careerism has a negative impact on employee performance. However, one of the study's findings is that employees' perceptions of ethical leadership have a positive impact on their performance. It is reasonable to assume that having a leader who is concerned about ethical codes, communicates well with employees, and considers employees' opinions in the decision-making process will prevent careerist orientation in the hotel business. It is possible that, in hotels where labor is the most important factor, employee performance will improve if careerism, a negative organizational tendency, is avoided.
\end{abstract}

Keywords: Ethical Leadership, Careerism, Employee Performance, Hotel Business.

Received: 15.07.2021

Accepted: 01.11.2021

Suggested Citation:

Dülger, E. and Cinnioğlu, H. (2021). The Relationship Between Perception of Ethical Leadership, Careerism and Employee Performance in Hotel Business Employees: The Case of İstanbul, Journal of Social, Humanities and Administrative Sciences, 4(11): 1090-1109. 


\section{Gíriş}

Zamanla değişen iş hayatı ve çalışma şartları, literatüre yeni örgütsel davranış türleri katabilmektedir ve bu davranış türleri negatif ya da pozitif olabilmektedir. Negatif davranış türlerinden biri olarak ele alabileceğimiz kariyerizm, kariyerini performansa bağlı olmadan sürdürme eğilimi olarak tanımlanmıştır (Feldman ve Weitz, 1991:237). İşgörenlerin bu davranış biçimini benimsemesi, özellikle zorlu çalışma koşulları olan, emeğin ön planda tutulduğu, esnek çalışma saatlerine sahip konaklama işletmelerinde işgören performansının objektif değerlendirilememesine yol açabilmektedir. İşgören performansı, işletmelerin hedeflerine ulaşabilmesi ve kişilerin de kariyer planları doğrultusunda ilerlemelerine katkı sağlayabilmesi açısından ise önem taşıyabilmektedir.

İşletme hedeflerine ulaşabilmek için işgörenlerin göstereceği performans düzeyinin hedeflere uygun olması ve bunu sağlarken misafirlerin memnuniyetinden de ödün verilmemesi, hizmet kalitesinin düşürülmemesi gerekmektedir. Bu noktada üst yöneticilerin nasıl bir yaklaşım izlediği önemlidir, çünkü işgörenlerin performans düzeylerini etkileyen faktörlerden biri de yöneticilerinden algıladıkları liderlik tarzıdır (Tekin, 2018:344; Cinnioğlu, 2019:2903). Konaklama işletmelerinde, işletme hedeflerine ulaşılabilmesi için liderin yapacağı yönlendirme ve sağlayacağı motivasyona ihtiyaç duyulması olasıdır. Bu tarz işletmelerde insanın öneminin farkında olmak ve liderlik tarzını bu doğrultuda şekillendirmek örgüt içindeki çalışan davranışlarını da etkileyebilmektedir.

Kariyerizm eğiliminin ortaya çıkmasının nedenlerinden biri de liderlerin oluşturduğu örgütsel çevredir. Kariyerizm davranışı etik bir örgütsel davranış olmadığı düşünüldüğünde, alınan kararların ahlak temelli olduğunu işgörenlere doğrudan hissettiren bir liderlik türü, bu negatif eğilimin ortaya çıkmasını engelleyebilecektir. Aynı şekilde, işgörenlerin yeterince motive olmasını sağlayarak çalışma performanslarını örgüt hedeflerine uygun bir hale getirecek olan yine o örgütün lideri olmalıdır. Negatif örgütsel davranış eğilimlerinin ortaya çıkmasına engel olan bir lider, aynı zamanda motivasyon da sağladı̆̆ı takdirde, işgören performansını etkileyebilecektir. Alanyazında pek çok liderlik tarzı bulunmasına rağmen hangi liderlik tarzının söz konusu değişkenler üzerinde örgüt için olumlu olabilecek sonuçlar yaratacağının tespit edilmesi oldukça önemlidir. Bu çalışmanın temel amacı, konaklama işletmesi çalışanlarının etik liderlik algısının kariyerizm ve işgören performansı üzerindeki etkisini belirlemek ve kariyerizm ile işgören performansı arasındaki ilişkiyi ortaya koymaktır. Bu amaçla yapılan alanyazın taraması ile değişkenlerin kuramsal çerçevesi oluşturulmuş, daha sonra İstanbul ilinde bulunan 5 yıldızlı otel çalışanlarından anket yöntemi kullanılarak veriler elde edilmiştir.

\section{KURAMSAL ÇERÇEVE}

Bu bölümde, sırasıyla etik liderlik, kariyerizm ve işgören performansı ile ilgili yapılmış çalışmalardan ulaşılan bilgiler sunulacaktır. Sonrasında ise, değişkenler arası ikili ilişkiler ile ilgili alanyazın taraması sonuçları verilerek buna bağlı olarak geliştirilen hipotezler sunulacaktır.

\section{Etik Liderlik}

Fransızca'da "ahlak, ahlaki" anlamında kullanılan "éthique" kelimesi, Türkçe'ye "etik" olarak geçmiş ve günümüzde "çeşitli meslek kolları arasında tarafların uyması veya kaçınması gereken davranışlar bütünü, töre bilimi, ahlaki, ahlakla ilgili" anlamlarına karşılık gelmektedir (NES, 2021; TDK, 2021). Lider ise, örgütün amaçlarına ulaşabilmesi için izlenecek yolu belirlenmesini sağlayan, değişimi ve gelişimi başlatan, önderlik ettiği topluluğa ilham veren ve onlara motive 
edebilen kişilerdir. Kısacası, liderler önderlik edilen topluluğa duygusal ve manevi açıdan hitap eder (Durgut, 2020:35). Etik liderler bunu yasal güçlerle değil, kendi kişilik özellikleriyle sağlarlar. Yani etik liderler için önemli olan, durumun yasal olup olmaması değil, ahlaki olup olmamasıdır (Erdilek Karabay, 2015:85). Kurallar etik liderler için sadece bir rehber görevi görebilir, kesinlikle etik kararın bir parçasını oluşturmaz (Aronson, 2001:249).

Liderlik kavramının etik davranışlar ile bir araya geldiği etik liderlik tarzı üzerine yapılmış ilk çalışmalardan biri Georges Enderle'ye aittir. Enderle (1987:658), "Yönetsel Etik Liderlik" olarak adlandırdığı bu liderlik tarzını, karmaşık durumlarda karar verme sorumluluğu almak olarak tanımlamıştır. Brown, Treviño ve Harrison'a (2005:120) göre; etik lider iki yönlü iletişim ile ilişkileri destekleyerek örgüt içinde bireysel olarak ve kişilerin kendi aralarındaki ilişkilerin ahlak kuralları çerçevesinde olmasını sağlar. 13. yüzyılda yaşamış bir rahip olan Thomas Aquinas'a göre kişinin davranışının etik niteliği üç unsura bağlı olarak değerlendirilmelidir; kişinin niyeti, davranışı ve davranışın gerçekleştiği sosyal bağlam. Bu üç faktörden yola çıkıldığında, liderin etik olabilmesi için diğer insanlara faydası olan erdemli davranışları olmalıdır ve onlara zarar verebilecek davranışlardan kaçınmalıdır (Kanungo, 2001:259). Liderin etik sayılıp sayılamayacağına karar verirken esas beklenti, liderin üyelerini örgüte, bu örgütün diğer üyelerine, diğer paydaşlara ve toplumun geneline fayda sağlayacak amaç ve hedeflere rehberlik ederek yönlendirmesidir (Kanungo, 2001:260). Aronson'a göre ise (2001:251) liderin etik olup olmadığını belirleyen temel unsur, onun ahlaki gelişim düzeyi ya da fedakarlık seviyesidir.

Etik liderliği benimseyen yöneticiler, etiğe uygun buldukları davranışları ödüllendirip etik dışı davranışları disipline ettikleri için, işgörenleri istenen olumlu örgütsel davranışlara teşvik etmektedirler. Buna ek olarak liderin kendisi de etik davranışları ile işgörenlerine etiğin önemini kavramasını sağlar ve bu sayede işgörenlerin etik dışı davranışlarda bulunma olasılığını düşük seviyeye indirger (Mayer, Aquino, Greenbaum ve Kuenzi, 2012:153).

Otel işletmelerinde ve aslında tüm işletmelerde yöneticilerin etik liderlik tarzını benimsemesi, alınan kararları meşrulaştırmayı, örgüt kültürünü tutarlı ve dengeli bir hale getirmeyi ve güçlendirmeyi sağladığı gibi; işgörenler, misafirler ve diğer paydaşlar ile olan ilişkiyi de sağlamlaştırır (Nicolaides, 2019:6)

Etik liderlik ile ilgili turizm işletmelerinde yapılmış birçok çalışma bulunmaktadır. Yeşiltaş vd., (2012) otel işletmeleri üzerinde yaptıkları çalışmada, etik liderlik algısının örgütsel sapma davranışlarını negatif yönde, örgütsel adaleti ise pozitif yönde etkilediği sonucuna ulaşılmıştır. Zhu, Sun ve Leung (2014) ile Şentürk, Boğan ve Bayırlı'nın (2019) çalışmaları sonucunda, etik liderliğin kurumsal sosyal sorumluluğu olumlu etkilediği görülmüştür. Khuong ve Nhu'nun (2015) turizm sektöründe çalışanlar ile yaptıkları araştırma, etik liderliğin çalışanların sosyallik düzeylerini ve örgütsel bağlllıklarını olumlu yönde etkilediğini göstermiştir. Eşitti'nin (2019), restoran çalışanları ile yaptığı çalışma, etik liderliğin servis iklimi ile örgütsel bağlılığı olumlu yönde etkilediği göstermiştir. Bu çalışmalarda da görülebileceği gibi, etik liderlik turizm işletmelerinde de olumlu örgütsel davranışları pozitif yönde etkilerken, olumsuz örgütsel davranışlara negatif etki etmektedir.

\section{Kariyerizm}

Yönetim anlayışının zamanla değişmesi, örgüt içi davranışları da etkilemekte, bunun bir sonucu olarak olumlu ya da olumsuz olarak değerlendirilen örgütsel davranış türlerine yeni kavramlar katılabilmektedir. Kariyerizm, olumsuz olarak nitelendirilen bir örgütsel davranış biçimi olmakla birlikte, örgüt içinde performans göstermeden ilerleme amacı güden kişileri tanımlamaktadır (Feldman ve Weitz, 1991:237). Skopec'e (2019:99) göre kariyerizm eğilimi, kişinin psikopati 
eğilimi sonucunda ortaya çıkan, suçluluk, empati ve benzeri duygusal eksikliklere sebep olması ile fark edilebilen ayrıca antisosyal davranışların da öncülü olabilen bir çeşit davranış bozukluğudur.

1960 'lı yıllara kadar iş dünyasında yönetim anlayışı, çalışanlar için bir kariyer planı vadediyor olsa da 20. yüzyılın 2. yarısından itibaren farklı bir yönelim ortaya çıkmıştır. İşverenlerin çalışan adaylarından beklentileri artmış ancak örgüt içinde onlara bir kariyer yolu gösterme anlayışından uzaklaşarak bir çalışanın ömür boyu aynı örgütte kalması yaklaşımını benimsemeye başlamışlardır (Peiperl ve Baruch, 1997:11; Millerd, 2021). Bu durumu, Whyte'ın (1956:161) “Bu kadar hızlı değişen ve sonsuza kadar hareket halinde olması gereken bir dünyada, bir bireyin umutsuzca kök salmaya ihtiyacı vardır ve örgüt bireyin köklerini geliştirebilmesi için mantıklı bir yerdir" sözleri özetlemektedir. Bu anlayışı uygun bulmayan ve işvereninden kendisine uygun nitelikte bir kariyer planı göremeyen işgörenler zaman içerisinde kendi kariyer planlarını ele alarak ilerleme yoluna gitmişlerdir (Peiperl ve Baruch, 1997:11; Seçer ve Çınar, 2011:51). Kendi kariyer inisiyatifini elinde bulunduran bireyler arasında, örgütten bağımsız hareket eden bireylerin artmasının kariyerizm davranışlarının ortaya çıkışına zemin hazırladığı söylenebilir (Doğan ve Dülger, 2020: 70).

Özdemir ve Üzüm (2019:132) kariyerist bireylerin başarı devamlığına verdikleri önemi ve örgüt içindeki diğer kişilerin başarısızlığına sebebiyet verebilecek bu davranışlarını yengeç sendromu ile bağdaştırmaktadır. Kariyeristlerin izlenim yönetimi uygulayarak sergiledikleri manüpülatif taktikler, örgüt içinde olumsuz sonuçlara yaratırken bireye katkı sağlamaktadır (Bratton ve Kacmar, 2004:295; Whitaker, 2011:1). Zaten kariyerizm, bireyin kendi çıkarlarının örgütün vaatleriyle uyuşmadığını fark edip kısa vadeli planlar ile örgüt çıkarlarını yok sayarak kendi çlkarları doğrultusunda hareket etme güdüsüdür (Hall, 1976:127; Chay ve Aryee, 1999: 620; Chiaburu, Munõz ve Gardner, 2013: 473; Üzüm, 2018: 5353).

Kariyerizm üzerine yapılan çalışmalarda kariyerizmin işten ayrılma niyeti (Chay ve Aryee, 1999: 620), işlemsel psikolojik sözleşme (Hamilton ve Treuer, 2012:488), psikopati eğilimi, değişim ideolojisi (Chiaburu vd., 2013:484), yıkıcı olağandışı işyeri davranışları (kişilerarası ve örgüte karşı) ve yapıcı olağandışı işyeri davranışlarından meydan okuyucu davranış (Yıldız, Yıldız ve Alpkan, 2015:688); zorunlu vatandaşlık davranışı (Yıldız ve Ayaz Arda, 2018:159), normatif ve devam bağlılığını (Jain ve Sullivan, 2020: 1563) olumlu yönde; örgütsel bağlllık (Chay ve Aryee, 1999: 620), örgütsel güven (Aryee ve Chen, 2004:326), örgütsel vatandaşlık, yaşam doyumu (Adams, 2011:188), ilişkisel psikolojik sözleşme (Hamilton ve Treuer, 2012:488), duygusal bağlılık, örgütsel tatmin, örgüt performansı (Jain ve Sullivan, 2020: 1563) davranışlarını ise olumsuz yönde etkilediği görülmüştür. Bu çalışmalar aracılı̆̆ı ile kariyerizm davranışının olumlu örgütsel davranışları olumsuz, olumsuz örgütsel davranışları ise olumlu şekilde etkileyerek örgüte zarar verdiği de söylenebilir.

Turizm sektörünün çalışma koşulları ele alındığında, var olan sektörel şartlarla birlikte kariyerizmin yol açabileceği iş tatmini, örgütsel bağlllık gibi olumlu tutumların negatif yönde etkilenmesinin sektörel sıkıntılardan biri olan personel devir oranında artışa yol açabileceği öngörülebilir (Doğan ve Dülger, 2020:78). Sektörün ağırlıklı olarak genç nüfus ile istihdam ediliyor olması ve kariyerizm eğiliminin daha çok söz konusu yaşlarda görülmesi, turizm işletmelerinde bu eğilimin ortaya çıkma ihtimalinin göz ardı edilmemesi gerektiğini göstermektedir (Girdap, Giden ve Özdemir, 2019:63-65; Doğan ve Dülger, 2020:78). 


\section{İşgören Performansı}

Fransızca'dan İngilizce'ye yine aynı şekilde geçen "performance" sözcüğü, dilimizde de "performans" olarak kullanılmakta ve Türk Dil Kurumu sözlüğünde de karşılığında "başarım" kelimesi yer almaktadır (TDK, 2021). Alan yazına bakıldığında, performansın tek bir tanımı olmamakla beraber birçok boyuta da sahip olduğu görülmektedir (Ghalem vd., 2016:3). Samsonowa (2012:23), alan yazındaki tüm bu tanımların iki ortak özelliği olduğunu savunmaktadır; hedefe ulaşma derecesini gösteren etkinlik ve başarılı olmak için tüketilen kaynakların göstergesi olan verimliliktir. Alan yazında performans hakkında çeşitli tanımlamalarla karşılaşabiliriz. Lebas ise performansı, iş yeri ve durumuna özgü kısıtlamalarla belirtilen hedeflerin elde edilmesini sağlayan yöntemleri doğru şekilde paylaştırmak ve yönetmek olarak tanımlar (Lebas, 1995:29). İşgören performansı, Sverke vd.'nin tanımına göre; bir bireyin belirli bir zaman diliminde gösterdiği davranışların işletmenin beklentilerine uygunluğudur. Burada bireyin davranışları, olumlu veya olumsuz yönde etkileyebilir (Sverke vd., 2019:4).

İsgören performansı, tüm işletmeler için işletme hedeflerine giden yoldaki en önemli faktörlerdendir. Yüksek performansa sahip işgörenlere sahip olan bir örgütün, hedeflerine ulaşabilmesi daha kolay gerçekleşmektedir (Ali, Bin, Piang ve Ali, 2016:301). Turizm sektörünün emek ağırlıklı performans gerektiren bir sektör oluşu, işgören performansını rekabet açısından da önemli kılmaktadır (Kocaman, 2017:66), çünkü bu sektörde işgörenler, sağlanan hizmetin en temel unsurudur (Arslantürk, 2009:23). Otel işletmelerinde, sunulan ürün ve hizmetler bütününün kalite düzeyini belirleyen, "insan"dır (Özer, 2019:1014). Bu nedenle, otel işletmelerinde performansın yönetilmesi ve değerlendirilmesi adına atılacak adımların önemli olduğu düşünülebilir. Çünkü bu işletmelerde performanslara etki eden faktörlerin tespit edilebilmesi, çalışan işgörenlerin her birinin performanslarının şeffaf ve adaletli bir şekilde ortaya konulmasına bağlıdır (Çöp ve Doğanay, 2020:37).

\section{Etik Liderlik, Kariyerizm ve İşgören Performansı İlişkisi}

Kariyerizm eğilimi; etik dışı yollarla, manüpülatif davranışlarla, menfaat için sosyal ilişkilerin kurulmasıyla ve performans göstermeksizin kariyer ilerlemesi sağlamaya çalışmaktır (Feldman ve Weitz, 1991:238). Etik liderliğin ise kariyerist eğilim sahibi kişilerde görülen bu etik dış1 davranışları ve sahte performans gösterme eylemlerini, ahlaki yol göstericilik ve işgörenlere gösterilen ilgi sayesinde azaldığı ortaya konulmuştur (Khuntia ve Suar, 2004:24).

Kariyerist eğilim, Chay ve Aryee (1999:620) tarafından ortaya konulduğu üzere, örgüte duyulan güvensizlikle desteklenmektedir. Bundan yola çıkarak, etik kodların daha net olmasını sağlayan, örgüt içinde tüm işgörenlerin aynı şekilde algıladığı bir etik iklim yaratan ve yarattığı bu iklim içinde sahip olduğu etik ilkeleri işgörenlere de aşılayan bir liderin varlığının kariyerist eğilimin önüne geçebileceği öngörülebilir (Yıldız ve Ayaz Arda, 2018:162).

Şengüllendi, Şehitoğlu ve Kurt (2020), bankacılık sektöründe gerçekleştirdikleri çalışmalarında, toksik liderlik tarzının kariyerizm eğiliminde artışa neden olacağını göstermişlerdir. Ayrıca Liman, Elçi ve Murat (2019) kamu ve özel sektörde yaptıkları çalışma sonucunda etik liderliğin kariyerizm üzerinde anlamlı ve negatif bir etkisi olduğunu ortaya koymuşlardır. Bu çalışmalara göre, işgörenlerin algıladıkları liderlik tarzı, kariyerizm eğilimini etkileyebilmektedir. Çalışmaların sonuçları ışığında aşağıda yer alan hipotez kurulmuştur:

H1: Etik liderliğin kariyerizm üzerinde anlamlı bir etkisi vardır. 
Ekonomik koşulların hızla değişmesi ve rekabet ortamının artması ile işgören performansının arttırılması, bunun sayesinde de işletmenin performansının yükseltilmesi önem kazanmıştır (Yozgat, Yurtkoru ve Bilginoğlu, 2013). Bir işletme yöneticisinden de işletmenin amaç ve hedefi doğrultusunda işgörenleri motive etmesi ve bunun aracılığı ile de performanslarında artış sağlaması beklenir. Çünkü performans, örgüt için olduğu kadar işgörenin kendisi için de kariyer hedeflerine ulaşabilmesi açısından önemlidir. Bu demektir ki, yöneticinin tercih ettiği liderlik tarzı, işgörenin potansiyelini ortaya çıkararak performansını arttırmak açısından oldukça önemlidir (Demirel, 2017:382). Ayrıca Chiaburu, Munõz ve Gardner'a göre (2013:474), çalışma çabasının örgütün muamelesine bağlı olması gerektiği inancı (değişim ideolojisi) (Eisenberger, Huntington, Hutchison ve Sowa, 1986) yüksek olan kişiler, örgütte ancak iyi muamele gördüklerinde çok çalışmaktadırlar. Bunun bir sonucu olarak, etik liderlik algısının yüksek olmasının işgören performansına olumlu etkileri olabileceği düşünülebilir.

Etik liderlikte yönetici davranışlarının çalışanların örgüt içindeki tutum ve davranışları üzerinde, bunun sonucu olarak da iş ve dolayısı ile örgüt performansı üzerindeki etkilerinin olumlu olması beklenir (Aronson, 2001:254; Kanungo, 2001:258; Brown vd., 2005:122). Yapılan birçok çalışmada, etik liderliğin işgören performansı üzerinde pozitif etkisi olduğu ortaya konulmuştur (Ayan, 2015; Khuong ve Quoc, 2016; Khokhar ve Zia-ur-Rehman, 2017; Zehir, Erdal, Sivaslıoğlu ve Demir, 2018; Zulhelmi, Bustari Muchtar ve Abror, 2018; Shafique, Kalyar ve Ahmad, 2018; Nguyen ve Luu, 2019). Bu çalışmalar doğrultusunda, etik liderlik algısının otel işletmelerinde de işgören performansını etkileyebileceği öngörülerek aşağıda yer alan hipotez kurulmuştur:

H2: Etik liderliğin işgören performansı üzerinde anlamlı bir etkisi vardır.

Kariyerizm yönelimi, Feldman ve Weitz'ın (1991:237) da ortaya koyduğu üzere, performans göstermeksizin, yanıltıcı algı sağlayarak başarılı görünüp kariyerlerinde ilerleme kaydetmeye çalışmaktır. Ayrıca kariyerist bireylerin sahip olduğu özellikler olan kişisel çıkarlara yönelik davranarak sosyal yükümlülükleri yerine getirmeme, karşllıklılık normuna uymama, sorumsuz davranma ve işlerine önem vermeme davranışları, performans düşüklüğü yaratacaktır (Chiaburu vd., 2013:475). Kariyeristler, sosyal ilişkilerini kariyer ilerlemelerine katkı sağlama amacı ile kurarlar (Feldman ve Weitz, 1991:238) ve bu sosyal ilişkilerin politik olması dolayısı ile kendilerinden beklenen performansa adapte olmaktansa bu ilişkileri güçlendirme eğilimine girerler (Hsiung, Lin ve Lin, 2012:263). Bu çalışmalardan yola çıarak, kariyerizmin işgören performansını etkileyebileceği sonucuna varılarak aşağıda yer alan hipotez ve model kurulmuştur:

H3: Kariyerizmin işgören performansı üzerinde anlamlı bir etkisi vardır.

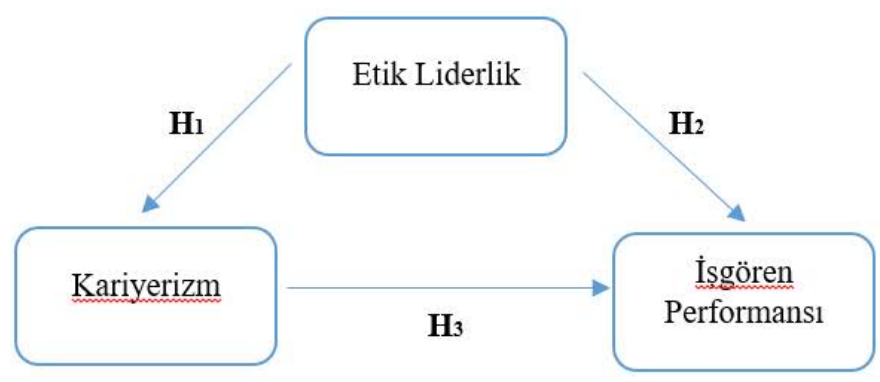

Şekil 1: Araştırmanın Modeli 


\section{YÖNTEM}

Bu çalışmada, araştırma yöntemi olarak nicel araştırma yöntemi tercih edilmiştir. Tewksbury (2009:39), nicel araştırma yöntemini genellikle sosyal bilimler alanında araştırma yapmak için daha bilimsel bir yaklaşım olarak görüldügünü belirtmiştir.

\section{Araştırmanın Amacı ve Önemi}

Alanyazın incelendiğinde, liderlik tarzlarının örgütsel davranışlar üzerinde negatif ya da pozitif etkilere sahip oldukları, dolayısı ile örgüt üzerinde önemli bir etkiye sahip olduğu söylenebilir. Yoğun iş temposuna sahip otel işletmelerinde de, işgörenin motivasyonu, örgüt içindeki davranışları, performansı ve dolayısı ile işletme hedeflerine ulaşılabilmesi için, yöneticilerin benimseyeceği liderlik tarzının önemli olacağı söylenebilir (Demirel, 2017:382). Etik liderlik algısının bulunduğu turizm işletmelerinde; kurumsal sosyal sorumluluk (Zhu vd., 2014), işgören sosyalliği (Khuong ve Nhu, 2015), örgütsel bağlllık (Khuong ve Nhu, 2015; Çelik, Dedeoğlu ve İnanır, 2015), iş tatmini (Çelik vd., 2015), lider-üye ilişkisi (Dhar, 2016) gibi örgütsel davranışların bu liderlik tarzından olumlu etkilediği ortaya konulmuştur. Çalışmalarda da görüldüğü gibi, etik liderlik tarzının benimsenmesi ile örgüt içinde gelişebilecek negatif davranışların önüne geçilebileceği ayrıca olumlu davranışları teşvik edebileceği düşünülebilir.

Turizm işletmeleri özelinde yapılan çeşitli çalışmalar işgören performansını; çaba, rekabet gücü, öz yeterlilik (Karatepe vd., 2006), eğitim, güçlendirme ve ödül (Karatepe, 2013), işgören odaklı liderlik davranışı, üretim odaklı liderlik davranışı (Demirel, 2017), algılanan hizmetkâr liderlik (Cinnioğlu, 2019), dönüşümcü liderlik (Aktuna ve Kılıçlar, 2019) gibi etkenlerin olumlu; stresin (Kalyar vd., 2019) ise olumsuz etkilediğini göstermiştir. Bu çalışmalara dayanarak, işgören performansının liderlik tarzlarından ve diğer örgütsel davranışlardan etkilemesi mümkün olduğu görülmektedir.

Yapılan çalışmalara göre ahlaki çözülmenin kariyerizme yol açtığı (Ağırbaş, 2019:70) ve örgütlerce yıkıcı olağandışı işyeri davranışlarına yol açabilen bir davranış türü olduğu için (Yıldız vd., 2015:688) fark edilip önlem alınması ya da doğru yönetilmesi önemlidir. Performanstan bağımsız olarak kariyerlerinde ilerleme sağlayabileceklerine inanan kariyerist eğilim gösteren kişiler (Feldman ve Weitz, 1991:237), emek yoğun çalışılan bir sektör olan otel işletmelerinde önemli bir faktör olan işgören performansını etkileyebileceği düşünülebilir. Liderlik tarzları arasından bu çalışma için etik liderliğin seçilme nedeni, etik liderin ahlaki tutum sergileme özelliklerinin (Aronson, 2001:251; Mayer vd., 2012:153) kariyerizme yol açan ahlaki çözülmeye engel olup olamayacağını açıklayabilmektir. Çalışma, otel işletmelerinde etik liderlik tarzının benimsenmesi halinde kariyerizm davranışının önüne geçilebilmesi ve işgörenlerin performansına olan etkisinin ortaya konulması bakımından işletme hedeflerine ulaşma açısından yol gösterici nitelikte olabilecektir. Bu sebeplere dayanarak, bu çalışmanın temel amacı, otel işletmesi çalışanlarının etik liderlik algısının kariyerizm ve işgören performansı üzerindeki etkisini belirlemek ve kariyerizm ile işgören performansı arasındaki ilişkiyi ortaya koymaktır.

\section{Evren ve Örneklem}

Çalışmanın evrenini, İstanbul ilinde faaliyet gösteren konaklama işletmelesi çalışanları; örneklemini ise, bu şehirde bulunan 5 yıldızlı otel işletmelerinde çalışan personel oluşturmaktadır. Araştırmanın evreninin İstanbul olarak seçilmesinin temel nedeni otellerin neredeyse yılın 12 ayı hizmet vermesi, ülkemizdeki otellerin yoğun olarak bulunduğu illerin başında gelmesidir. İstanbul ilinde 2020 yılı itibari ile 23'ü turizm yatırım belgeli 125'i işletme 
belgeli toplamda 138 adet 5 yıldızlı otel işletmesi bulunmaktadır. Bu otel işletmelerinde istihdam edilen personelin sayısı hakkında kesin bir bilgiye erişilemediği için evren sonsuz kabul edilerek bu durumlarda kullanılan formül ile örneklem büyüklüğü 0,95 güven düzeyinde hesaplanarak 384 kişi olarak kabul edilmiştir (Ural ve Kılıç, 2013:45). Ankete katılan kişiler, basit tesadüfi örneklem yöntemi ile seçilmiştir.

\section{Veri Toplama Araci}

Çalışmada, veri toplama aracı olarak anket tekniği kullanılmıştır. Söz konusu anket 2 bölümden oluşmaktadır. Anketin ilk bölümünde değişkenlere yönelik ifadeler bulunmaktadır. Cevaplandırılması amacı ile 5'li likert ölçeği verilmiştir, derecelendirilmesi ise (1) Kesinlikle katılmıyorum - (5) Kesinlikle katılıyorum şeklindedir. Anketin ikinci bölümünde katılımcıların demografik bilgilerine yönelik sorular bulunmaktadır. Araştırmanın amacı doğrultusunda kullanılan tüm ölçekler, daha önce Türkçeleştirilerek birçok çalışmada geçerliliği ve güvenilirliği tekrar sınanmış ölçeklerdir. Anket çalışması, sürecin pandemi dönemine denk gelmesi nedeni ile Nisan - Haziran 2021 tarihleri arasında katılımcılara internet üzerinden iletilmiş ve yanıtlar da yine internet üzerinden alınmıştır. Bu araştırma kapsamında yapılan anket formu için İskenderun Teknik Üniversitesi Bilimsel Araştırma ve Yayın Etiği Kurulu tarafından onay alınmıştır (11.03.2021-4710).

Toplamda 430 anket gönderilmiş, 408 tanesinde geri dönüş sağlanmış, eksik ve hatalı anketler çıkarıldıktan sonra 398 anket analize dahil edilmiştir. Anketlerden elde edilen sonuçlar, istatistik paket programı üzerinden değerlendirilmiştir.

Etik Liderlik Ölçeği: Tek boyut ve 10 ifadeden oluşan etik liderlik ölçeği, Brown vd.'nin (2005) yılında yaptıkları çalışmadan Tuna, Bircan ve Yeşiltaş (2012) tarafından Türkçeleştirilerek geçerliliği ve güvenilirliği test edilmiştir. Ölçek, Türkçe olarak daha sonra da bir çok çalışmada kullanılmış, geçerlilik ve güvenilirlikleri tekrar sınanmıştır (Yeşiltaş, Çeken ve Sormaz, 2012; Kesen, 2016; Erol ve Göktaş Kulualp, 2019; Durgut, 2020).

Kariyerizm Ölçeği:Bu çalışmada, katılımcıların kariyerizm eğilimini ölçmek adına Feldman ve Weitz'ın (1991) geliştirtirdiği ve Yıldız (2015) tarafından kısaltılıp Türkçe'ye tercüme edilmiş olan tek boyutlu 7 ifadelik kariyerizm ölçeği kullanılmıştır. Türkçe'ye çevirilen ölçeğin geçerlilik ve güvenilirliği farklı çalışmalarda da tekrar test edilerek doğrulanmıştır (Yıldız vd., 2015; Ağırbaş, 2019; Girdap, 2019; Liman vd., 2019).

İşgören Performansı Ölçeği: Çöl (2008) tarafından Türkçe’ye çevirilmiş, tek boyut ve dört ifadeden meydana gelen, orjinali Kirkman ve Rosen (1999) ile Sigler ve Pearson (2000) çalışmalarından alınmış olan ölçek kullanılmıştır. Ölçek Türkçeleştirildikten sonra da pek çok çalışmada test edilerek geçerliliği ve güvenilirliği yeniden ispatlanmıştır (Yılmaz ve Karahan, 2010; Ayan, 2015; Tekingündüz, Kurtuldu ve Eğilmez, 2016; Tekin, 2018; Cinnioğlu, 2019; Cinnioğlu ve Güler, 2020; Turan ve Cinnioğlu, 2020).

\section{BULGULAR ve ANALIZZLER}

Katılımcıların demografik özelliklerine ilişkin bulgulara bakıldığında, \%73'ünün erkek (f: 284), \%62,7'sinin 1980-1999 yılları arasında doğum tarihine sahip (f: 244) ve \%44'ünün 2500-4000 TL arasında bir gelire (f: 171) sahip olduğu tespit edilmiştir. Aynı zamanda katılımcıların \%65,6'sının (f: 255 ) bekâr olduğu, \%51'9'unun turizm eğitimine (f: 202) sahip olmadığı, $\% 45,2^{\prime}$ sinin bir ile beş 
yıl arasında (f: 176) mevcut işletmede çalıştığı ve son olarak \%45,2'sinin lise (f: 176) mezunu olduğu belirlenmiştir.

Tablo 1. Ölçeklere Yönelik Açımlayııı Faktör Analizi

\begin{tabular}{|c|c|c|c|}
\hline & $\begin{array}{l}\text { Faktör } \\
\text { Yükleri }\end{array}$ & \begin{tabular}{|c|} 
Açılkanan \\
Varyans \\
$(\%)$
\end{tabular} & Özdeğer \\
\hline \multicolumn{4}{|l|}{ Etik Liderlik Ölçeği } \\
\hline $\begin{array}{l}\text { Liderim, başarıyı sadece sonuçlarla değil, aynı zamanda hangi yollarla } \\
\text { elde edildiğini tanımlar. }\end{array}$ & 873 & \multirow{10}{*}{64,821} & \multirow{10}{*}{6,482} \\
\hline Liderim güvenilirdir. & 872 & & \\
\hline Liderim, çalışanların ne söyleyeceklerini dinler. & ,863 & & \\
\hline Liderim, etik standartları çiğneyen işgörenleri disipline eder. & ,863 & & \\
\hline Liderim işgörenlerle iş etiği ve değerleri tartışır. & 800 & & \\
\hline Liderim, kişisel yaşamını etik davranış üzerine kurar. & 779 & & \\
\hline Liderim, işgörenin kafasındaki en iyi ilgiye sahiptir. & ,776 & & \\
\hline $\begin{array}{l}\text { Liderim, etik anlamda işlerin nasıl doğru yapılacağıyla ilgili örnek } \\
\text { oluşturur. }\end{array}$ & 770 & & \\
\hline Liderim, adil ve dengeli kararlar verir. & 738 & & \\
\hline Liderim karar alırken "Yapılacak en doğru şey nedir?" diye sorar. & 695 & & \\
\hline KMO: ,916 Sig=,000 $\quad$ Bartlett's Test: 2,978E3 & & & \\
\hline \multicolumn{4}{|l|}{ Kariyerizm Ölçeği } \\
\hline İşverene sadakat ödüllendirilmez. & ,885 & \multirow{7}{*}{67,903} & \multirow{7}{*}{4,753} \\
\hline $\begin{array}{l}\text { İlerleme kaydedilebilmesi için, bazen kurumun menfaatlerinden ziyade } \\
\text { kişisel gelişimi destekleyen eylemlerde bulunulması gerekir. }\end{array}$ & 864 & & \\
\hline $\begin{array}{l}\text { Başarılılık imajından istifade edilmesi önemlidir, zira başarılıymış gibi } \\
\text { görünmek, ilerleme kaydedilmesi konusunda yetkinlik kadar etkili } \\
\text { olabilir. }\end{array}$ & ,854 & & \\
\hline $\begin{array}{l}\text { Uzun vadede bireyin kariyer hedefleri kurumun çıkarları ile } \\
\text { örtüşmeyebilir; nihayetinde herkes kendi çıkarlarına hizmet eder }\end{array}$ & 848 & & \\
\hline $\begin{array}{l}\text { Bazen, kişinin hak ettiğini düşündüğü terfiyi alabilmesi için yanıltıcı } \\
\text { davranışlar sergilemesi gerekir. }\end{array}$ & ,790 & & \\
\hline Kurumlar içerisinde yalnızca liyakat ile ilerlemek zordur. & ,773 & & \\
\hline $\begin{array}{l}\text { Yükselmek için genellikle üstler, çalışma arkadaşları ve diğer } \\
\text { arkadaşlar ile sosyal ilişkilerden faydalanılması gereklidir. }\end{array}$ & 743 & & \\
\hline KMO: ,912 Sig=,000 & & & \\
\hline \multicolumn{4}{|l|}{ Performans Ölçeği } \\
\hline $\begin{array}{l}\text { Sunduğum hizmet kalitesinde standartlara fazlasıyla ulaştığımdan } \\
\text { eminim. }\end{array}$ & ,918 & \multirow{4}{*}{75,921} & \multirow{4}{*}{3,037} \\
\hline İşimde gösterdiğim performansın kalite düzeyi yüksektir & ,887 & & \\
\hline İş hedeflerime fazlasıyla ulaşırım. & ,862 & & \\
\hline Görevlerimi tam zamanında tamamlarım. & ,816 & & \\
\hline KMO: ,775 Sig=,000 & & & \\
\hline
\end{tabular}


Öncelikle araştırmada kullanılan ölçeklerin yapı geçerliliğini ortaya koymak için açıklayıcı faktör analizi yapılmıştır (Tablo 1). Etik liderlik ölçeğine yönelik olarak yapılan açımlayıcı faktör analizi neticesinde ölçeğin KMO (Kaiser-Meyer-Olkin Measure) değerinin 0,916 ve Bartlett's test değerlerinin ise anlamlı olduğu $(p=, 000)$ tespit edilmiştir. Tüm ifadelerin tek boyutta toplandığ 1 ölçeğin açıkladığı toplam varyans \% 64,821'dir. Faktör analizi sonucunda kariyerizm ölçeğindeki yedi ifade özdeğeri birden büyük tek boyutta toplanmış ve bu boyut toplam varyansın \%67,903'ünü açıkladığı görülmektedir (KMO: ,912; p=,000). Yapılan analiz neticesinde işgören performans ölçeğinin KMO değer 0,775, Bartlett's testi anlamlılık sonucunun ise 0,000 olduğu tespit edilmiştir. Tek boyut altında toplanan dört ifadenin açıkladığı toplam varyans oranı ise $\% 75,921$ 'dir.

Araştırmada kullanılan ölçeklere yönelik faktör analizleri yapıldıktan sonra bu faktörlerin güvenirlilik düzeyleri belirlenmiştir. Ölçeklerin Cronbach's Alfa değerlerine bakıldığında etik liderlik ölçeğinin ,939; performans ölçeğinin ,890 ve kariyerizm ölçeğinin ,920 olduğu görülmektedir (Tablo 2). Bu verilere göre araştırmada kullanılan ölçeklerin güvenirlilik düzeyinin yüksek olduğu (Cronbach's Alfa $\geq 0.60$ ) söylenebilir. Aynı tabloda yer alan değişkenlere yönelik ortalama değerlere bakıldığında ise çalışanların etik liderlik $(3,10)$ ve performans $(3,56)$ algılarının orta düzeyde olduğu, kariyerizm algılarının ise düşük düzeyde $(2,38)$ olduğu söylenebilir.

Tablo 2. Değişkenlerin Ortalama ve Cronbach's Alfa ve Korelâsyon Analizi Değerleri

\begin{tabular}{|l|c|c|c|c|c|c|c|}
\hline & $\mathrm{n}$ & Ort. & $\begin{array}{c}\text { İfade } \\
\text { Sayıs1 }\end{array}$ & $\begin{array}{c}\text { Cronbach's } \\
\text { Alfa }\end{array}$ & Kariyerizm & Performans & Etik Liderlik \\
\hline 1)-Kariyerizm & 389 & 2,38 & 7 &, 920 & 1 & & \\
\hline 2)-Performans & 389 & 3,56 & 4 &, 890 &,$- 260^{* *}$ & 1 & \\
\hline 3)-Etik Liderlik & 389 & 3,10 & 10 &, 939 &,$- 216^{* *}$ &, $296^{* *}$ & 1 \\
\hline
\end{tabular}

Değişkenler arasındaki ilişkilerin yönünü ve kuvvetini belirlemek amacıyla korelasyon analizi yapılmış ve sonuçlar Tablo 2'de verilmiştir. Analiz sonuçlarına bakıldığında etik liderlik ile kariyerizm ( $\mathrm{r}:-, 216 ; \mathrm{p}<.001)$ arasında negatif yönlü ve anlamlı bir ilişki, performans arasında ise pozitif yönlü ve anlamlı (r: ,296; p < .001) bir ilişki görülmektedir. Kariyerizm ile performans arasındaki korelasyon değerlerine bakıldığında ise iki değişken arasında negatif yönlü ve anlamlı (r: -,260; $\mathrm{p}<.001)$ bir ilişki tespit edilmiştir.

Algılanan etik liderliğin çalışanların kariyerizm algısı üzerindeki etkisini belirlemek amacıyla yapılan basit regresyon analizi sonucunda (Tablo 3), etik liderliğin kariyerizmdeki değişimin $\%, 04$ 'ünü açıkladığı ve kurulan modelin anlamlı olduğu $(\mathrm{p}=0,00)$ görülmektedir. Bununla birlikte analiz sonucunda etik liderlik davranışının kariyerizm üzerinde $0,17^{\prime}$ lik bir negatif etkiye sahip olduğu tespit edilmiştir. Aynı zamanda etik liderliğin işgören performansındaki değişimin $\%, 08^{\prime}$ ini açıkladığı ve algılanan etik liderlikteki bir birimlik artışın performans üzerinde 0,17'lik bir artışa neden olacağ belirlenmiştir. Bu analizler sonucunda araştırmada geliştirilen $\mathrm{H}_{1}$ ve $\mathrm{H}_{2}$ hipotezi kabul edilmiştir. 
Tablo 3. Etik Liderliğin Çalışanların Kariyerizm ve Performansına Etkisine Yönelik Basit Doğrusal Regresyon Analizi

\begin{tabular}{|c|c|c|c|c|c|c|}
\hline \multirow{2}{*}{\multicolumn{2}{|c|}{ Model }} & \multicolumn{2}{|c|}{$\begin{array}{c}\text { Standartlaştırılmamış } \\
\text { Katsayılar }\end{array}$} & \multirow{2}{*}{\begin{tabular}{|c|}
$\begin{array}{c}\text { Standartlaştırılmış } \\
\text { Katsayılar }\end{array}$ \\
Beta \\
\end{tabular}} & \multirow[b]{2}{*}{$\mathbf{t}$} & \multirow{2}{*}{$\begin{array}{l}\text { Anlamlılık } \\
\text { Düzeyi }\end{array}$} \\
\hline & & B & Std. Hata & & & \\
\hline \multirow[t]{2}{*}{1} & Sabit & 2,919 & ,130 & & 22,505 & ,000 \\
\hline & Etik Liderlik &,- 172 & ,040 &,- 216 & $-4,343$ & ,000 \\
\hline \multicolumn{7}{|c|}{ a.Bağımlı Değişken: Kariyerizm ( $R=, 216 ; R^{2}=0,046$; Düzeltilmiş $\left.R^{2}=0,044 ; F=18,861 ; p=0,00\right)$} \\
\hline & & \multicolumn{2}{|c|}{$\begin{array}{c}\text { Standartlaştırılmamış } \\
\text { Katsayılar }\end{array}$} & $\begin{array}{c}\text { Standartlaştırılmış } \\
\text { Katsayılar }\end{array}$ & & Anlamlilık \\
\hline \multicolumn{2}{|c|}{ Model } & B & Std. Hata & Beta & $\mathbf{t}$ & Düzeyi \\
\hline \multirow[t]{2}{*}{1} & Sabit & 3,009 & 096 & & 31,348 & ,000 \\
\hline & Etik Liderlik & ,179 & ,029 & ,296 & 6,087 &, 000 \\
\hline
\end{tabular}

Tablo 4. Çalışanların Kariyerizm Algısının Performans Düzeyine Etkisine Yönelik Basit Doğrusal Regresyon Analizi

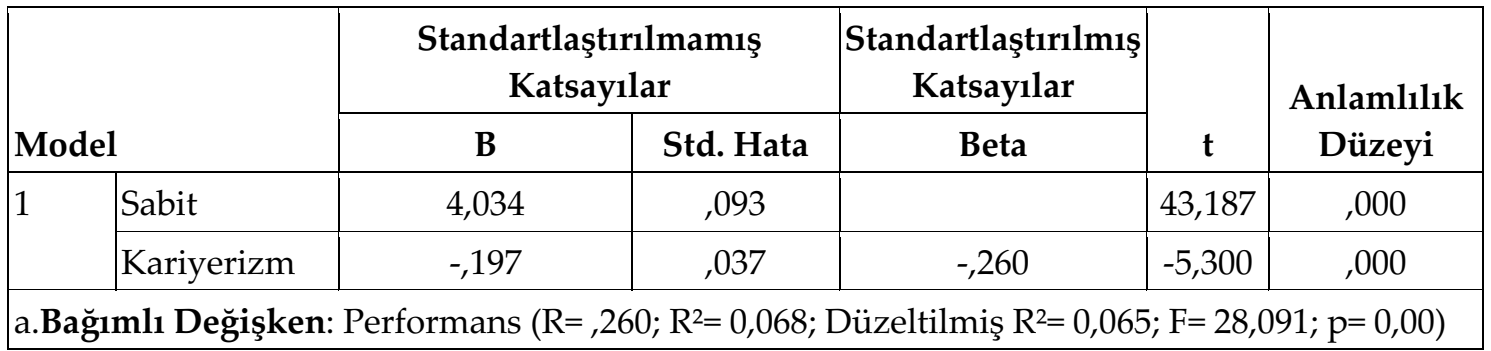

$\mathrm{H}_{3}$ hipotezinin test edilmesi için yapılan regresyon analizi neticesinde algilanan kariyerizmin işgören performansındaki değişimin \%,06'sını açıkladığı ve kariyerizm algısındaki bir artışın performansı 0,19 oranında azaltacağı sonucuna ulaşılmıştır (Tablo 4). Bu sonuca göre araştırmada geliştirilen $\mathrm{H}_{3}$ hipotezi kabul edilmiştir.

\section{TARTIŞMA, SONUÇ ve ÖNERİLER}

$\mathrm{Bu}$ çalışmanın temel amacı, konaklama işletmesi çalışanlarının etik liderlik algısının kariyerizm ve işgören performansı üzerindeki etkisini belirlemek ve kariyerizm ile işgören performansı arasındaki ilişkiyi ortaya koymaktır. Bu amaçla öncelikle literatür taraması ile değişkenlerin kuramsal çerçevesi oluşturulmuş, bu doğrultuda üç hipotez geliştirilmiş, bu hipotezleri test edebilmek amacı ile de İstanbul ilinde bulunan 398 beş yıldızlı otel çalışanından oluşan örneklemden anket yöntemi ile veri toplanmıştır. Bu verilerin analizi sonucunda önce işgören performansı, etik liderlik ve kariyerizm algılarının düzeyleri belirlenmiş, ayrıca etik liderlik ile işgören performansı, etik liderlik ile kariyerizm ve kariyerizm ile işgören performansı aralarındaki ilişkiler incelenmiştir. 
Çalışma sonucunda işgörenlerin etik liderlik algılarının, kariyerizm algısını ve işgören performansını; kariyerizm algısının da işgören performansını etkilediği görülmüştür. Etik liderlik ve performans algı düzeylerinin orta, kariyerizm algılarının ise düşük seviyede olduğu ortaya çıkmıştır. Ayrıca, etik liderlik algısının performans düzeyini pozitif yönde etkilediği saptanmıştır. Etik liderliğin kariyerizm algısını ve kariyerizm algısının da performans düzeyini negatif yönde etkilediği tespit edilmiştir. Bu sonuçlar, kariyerizm algısındaki artışın işgörenlerin performansını olumsuz etkileyeceğini, etik liderlik algısının ise kariyerizmin önüne geçebileceğini ayrıca işgören performansı üzerine olumlu etkileri olduğunu göstermektedir.

Khuntia ve Suar'ın (2004) çalışmalarında öne sürdükleri, yol gösterici, ilgili ve etik bir liderin varlığı, kariyerist kişilerde bulunan davranış özelliklerinin önüne geçtiği sonucu ile uyuşmaktadır. Yıldız vd., (2018) çalışmasında, etik bir iklim oluşturan, bu iklimde kendi etik ilkelerinin işgörenlere de yansımasını sağlayan bir liderin olması ile kariyerist yönelimin engellenebileceği sonucu da, $\mathrm{H}_{1}$ hipotezi ile paraleldir.

Chiaburu vd.'nin (2013), örgüt içinde iyi muamele gören personelin daha çok çalıştığı, bunun da performansa yansıdığı sonucu ile uyumludur. Etik liderlerin davranış tarzlarının örgüt üyelerine yansıması ile performans üzerinde olumlu etkiler sağlayacağı sonucuna varan Aronson'un (2011) çalışması, yine $\mathrm{H}_{2}$ hipotezi ile örtüşmektedir. İşletme hedeflerine göre işgöreni motive eden bir lider ile performansta artış sağlanabileceğini öne süren Demirel (2017) de $\mathrm{H}_{2}$ hipotezine paralel bir sonuca ulaşmıştır. Ayrıca $\mathrm{H}_{2}$ hipotezi, etik liderlik algısının işgören performansı üzerindeki etkisinin pozitif olacağı sonucuna varan başka pek çok çalışma ile de uyum göstermiştir (Ayan, 2015; Khuong ve Quoc, 2016; Khokhar ve Zia-ur-Rehman, 2017; Zehir, Erdal, Sivashığlu ve Demir, 2018; Zulhelmi, Bustari Muchtar ve Abror, 2018; Shafique, Kalyar ve Ahmad, 2018; Nguyen ve Luu, 2019).

Hsiung vd.'nin (2012) kariyerizm odaklı kişilerde görülen örgüt içi politik ilişkiler kurma davranışının çıkar amaçlı olması nedeni ile işlerine odaklanmak yerine ilişkilerini güçlendirme yoluna gittiklerini, bu durumun da performanslarında azalmaya neden olduğu sonucu ile paraleldir. Chiaburu vd.'nin (2013) kariyerist kişilerin gösterdiği algı yönetimi davranışlarının onları görevlerinden uzaklaştırdığı, dolayısı ile de performans düşüklüğü yaşadıkları sonucu da $\mathrm{H} 3$ hipoteziyle uyum göstermektedir.

Lidere duyulan güven, örgüt üyelerinin negatif örgütsel davranışlara yönelmesini engellemekte, pozitif örgütsel davranışlara yönelimi ise arttırabilmektedir. Bu sebeple, liderin örgütte güven ortamı yaratacak, adil ve ahlaki davrandığını işgörene hissettirecek bir tutum benimsemesi önemlidir. Ayrıca kariyerizm eğiliminin önüne geçmek adına da alınabilecek bazı önlemler mevcuttur. İşgörenin örgütteki varlığını başlatan işe alım sürecinde uygulanacak kişilik testi, işgörenin o örgütün kültürüne uyum sağlayıp sağlayamayacağını, kariyerist eğilimi olup olmadığını ortaya koyacaktır. Bu kişilik testleri, sadece işe alımda değil, bir rutin olarak kariyerist eğilimi fark etmek adına belirli aralıklarla uygulanabilir. Örgüt içinde bir kariyerizm eğilimi tespit edilir ise, bu eğilimin nedenlerini araştırıp o nedenleri ortadan kaldırmak yerinde olacaktır. Tüm çabalara rağmen bu eğilim ortadan kaldırılamıyorsa, örgütün bu eğilimden alacağı zararı en aza indirmek adına kariyerist bireyleri yönlendirmek gerekebilir. Bu süreçte kariyerist bireylerin takım çalışması, adanmışlık ya da gönüllülük gerektiren işlerden uzak tutulması uygun bir tercihtir. Émile de Girardin'in sözünden hareketle, "Yönetmek öngörmektir.". Negatif eğilimleri öngörerek önlemini alan bir lider, işletme hedeflerine ulaşma konusunda başarılı olacaktır denilebilir.

Otel işletmeleri, yapısal olarak zihinsel emeğin yanı sıra fiziksel emeğe de oldukça ihtiyaç duyulan, yoğun iş temposuna sahip, esnek ve uzun çalışma saatleri olan işletmelerdir ve bu işletmelerde işgörenlerin misafirlerle yüzyüze iletişim halinde olması gerekmektedir. $\mathrm{Bu}$ 
koşullar, işgörenlerin performans düzeylerini etkileyebilmekte, hatta yöneticilerinin kendileri için bir kariyer planı olmadığını görmeleri, örgütte güvensiz hissetmeleri gibi olumsuz algılar da negatif bir örgütsel davranış türü olan kariyerizmin ortaya çıkışına neden olabilmektedir. İşgörenlerin yüksek performans düzeyine ve düşük kariyerizm algısına sahip olmaları, yöneticilerinin tercih ettiği liderlik tarzına bağlı olabilmektedir. İşgörenleriyle iyi iletişim kuran, onlara etik davranan ve onların da örgüt içinde etik davranmasını, kendilerini güvende hissetmelerini sağlayan, karar alma aşamalarında işgöreniyle fikir alışverişinde bulunan bir liderin varlığı, işgörenlerin performanslarının artmasını ve kariyerizm algılarının düşük olmasını sağlayabilecektir.

İşletmeler için oldukça olumsuz sonuçlar yaratabilecek olan kariyerizm davranışının önüne geçebilmek için çeşitli önlemler almak mümkündür. Çalışmanın sonuçlarından da anlaşılabileceği gibi, bu davranış yönelimi engellemek için yöneticinin etik bir liderlik tarzı olması doğru bir hamle olarak görülebilir. Otel işletmeleri gibi fiziki emeğin ön planda olduğu ve hizmet kalitesinin de verilen bu emekten ileri gelen performansla orantılı görüldüğü işletmelerde; doğasında şeffaflık, işgörenlerle doğru iletişim, motive edici bir rehberlik taşıyan etik liderlik tarzı, sahte performans gösterme eğilimi olarak açıklanan kariyerizmin öncülleri olan nevrotik kişilik özellikleri, ahlaki çözülme gibi davranışları engelleyebilecektir.Örgütte mevcut olacak etik iklim ile işgörenleri kariyerizme iten endişeler yok edilebilecek ve bu da örgüte olan güvenlerini ve adalet duygularını yükselterek iş sürecini daha sağlıklı hale getirecektir (Chay ve Aryee, 1999:615; Liman vd., 2019:195). Ayrıca örgüt, çalışanlarına kendilerini değerli hissettirerek tatmin edici kariyer fırsatları sunduğu takdirde, örgüte zarar verebilmesi mümkün olabilecek kariyer yönelimlerinin ortaya çıkmasını azaltarak ihtiyaç duyduğu işgören performansını elde edebilecektir (Crawshaw, van Dick ve Brodbeck, 2012:5).

Bir işgörenin örgüt içindeki varlığı, işe alım ile başladığı düşünülürse, kariyerist eğilimin örgüt içine girmesine bu adımda müdahale etmek yerinde olacaktır (Doğan ve Dülger, 2020:76). Bu aşamada adayın kişiliğinde kariyerist eğilimin bulunup bulunmadığını görüşme sırasında yapılacak kişilik testleri ile anlamak mümkündür. Ayrıca yine bu aşamada adayın örgüt kültürüne uyumluluğu da değerlendirilmelidir ve son karar bu doğrultuda alınmalıdır (Yıldız vd., 2015:688; Yıldız, 2016:200; Girdap, 2019:63). Kişilik testlerinin yalnızca işe alım sürecinde kullanmak yerine örgütte belli aralıklarla uygulanarak bir rutin haline getirilmesi, yalnızca kariyerizmi değil, örgütte ortaya çıabilecek pek çok olumsuz örgütsel davranış biçimini tespit etmeye yardımcı olabilecektir (Ağırbaş, 2019:72).

Örgüt içinde mevcut bir kariyerizm eğilimi var ise, bu eğilimi örgüte faydalı hale getirmek yerinde bir müdahale olacaktır. Bu durumda kariyerizme neden olan faktörleri tespit edilmeli, bu faktörlerin önüne geçilemiyorsa kariyerist kişi gönüllülük gerektiren işlerden ve takım çalışmalarından uzak tutularak bireysel işlere yönlendirilmelidir (Yıldız vd., 2015:688; Liman vd., 2019:195).

Örgüt hedefleri için yüksek önem taşıyan işgören performansının değerlendirilmesi süreci, şeffaf, özenli ve objektif bir şekilde gerçekleştirilmelidir (Feldman ve Weitz, 1991:252; Cerdin ve Pargneux, 2014:2046; Girdap, 2019:64). Süreçte böyle bir yol izlenmesi ve süreç sonunda alınan sonuçlara göre ödüllendirme sağlanması ile kariyerist eğilime sahip kişilerin sahte performans göstermelerinin önüne geçilebilir ve işgörenler gerçek performanslarını ortaya koymaları için teşvik edilebilir (Kim, Kang, Lee ve McLean, 2016: 140; Ağırbaş, 2019:72).

$\mathrm{Bu}$ araştırmada katılımcıların anketteki ifadeleri objektik olarak cevapladıkları ve bu ifadelerin değişkenleri tam anlamıyla ölçebileceği varsayılmıştır. Araştırma sadece İstanbul ilinde faaliyet gösteren beş yıldızlı otel işletmesi çalışanlarını ile sınırlıdır, bu nedenle araştırma sonuçlarının genelleşitirilmesi doğru bir yaklaşım olmayabilir. Konuyla ilgili bundan sonraki yapılacak 
çalışmalarda farklı liderlik türleri incelenebilir. Aynı zamanda yiyecek içecek işletmetleri ya da seyahat acenteleri gibi farklı örneklem gruplarında uygulanabilir.

\section{KAYNAKÇA}

Ağırbaş, Z. B. (2019). Nevrotik Kişilik Özelliğinin Kariyerizm Eğilimi Üzerindeki Etkisinde Ahlaki Çözülmenin Aracı Etkisi, Yayınlanmamış Yüksek Lisans Tezi, İstanbul Üniversitesi, İstanbul.

Aktuna, H. C. ve Kılıçlar A. (2019). Yöneticilerin Liderlik Tarzları ile İşgörenlerin Performansı Arasındaki İlişki, Haliç Üniversitesi Sosyal Bilimler Dergisi, 2(2): 299-322.

Ali, A., Bin, L. Z., Piang, H. J. and Zulfiqar, A. (2016). The Impact of Motivation on The Employee Performance and Job Satisfaction in IT Park (Software House) Sector of Peshawar, Pakistan, International Journal of Academic Research in Business and Social Sciences, 6(9): 297-310.

Aronson, E. (2001). Integrating Leadership Styles and Ethical Perspectives, Canadian Journal of Administrative Sciences, 18(4): 244-256.

Arslantürk, Y. (2009). Dört ve Beş Yıldızlı Konaklama İşletmelerinde Performans Değerlendirme: Ankara İli Örneği, İşletme Araştırmaları Dergisi, 1(2): 19-34.

Aryee, S. ve Chen, Z.X. (2004). Countering The Trend Towards Careerist Orientation in The Age of Downsizing: Test of A Social Exchange Model, Journal of Business Research, 57: 321-328

Ayan, A. (2015). Etik Liderlik Tarzının İş Performansı, İçsel Motivasyon ve Duyarsızlaşma Üzerine Etkisi: Kamu Kuruluşunda Bir Uygulama, Eskişehir Osmangazi Üniversitesi İ̈BF Dergisi, 10(3): 117- 141.

Bratton, V.K. and Kacmar, K.M. (2004). The Dark Side of Organizational Behavior, (Editör) Ricky W. Griffin, Anne O'Leary-Kelly: Extreme Careerism - The Dark Side of Impression Management içinde (ss. 291-308). San Francisco, CA: John Wiley \& Sons, Inc.

Brown, M. E., Treviño, L. K. and Harrison, D. A. (2005). Ethical Leadership: A Social Learning Perspective for Construct Development and Testing, Organizational Behavior and Human Decision Processes, 97(2): 117-134.

Cerdin, J.L. and Pargneux, M.L. (2014). The Impact of Expatriates' Career Characteristics on Career and Job Satisfaction, and Intention to Leave: An Objective and Subjective Fit Approach, The International Journal of Human Resource Management, 25(14): 2033-2049.

Chay, Y.W. and Aryee, S. (1999) Potential Moderating Influence of Career Growth Opportunities on Careerist Orientation and Work Attitudes: Evidence of The Protean Career Era in Singapore, Journal of Organizational Behavior, 20(5): 613-623.

Chiaburu, D. S., Muñoz and G. J., Gardner, R. G. (2013). How To Spot A Careerist Early On: Psychopathy and Exchange Ideology As Predictors of Careerism. Journal of Business Ethics, 118(3): 473-486.

Cinnioğlu, H. (2019), Hizmetkâr Liderlik Davranışının Örgütsel Özdeşleşme ve İşgören Performansı Üzerine Etkisi: Restoran Çalışanları Üzerinde Bir İnceleme, İşletme Araştırmaları Dergisi, 11(4): 2902-2911.

Cinnioğlu, H. ve Güler, M. (2020). Restoran İşletmeleri Çalışanlarının Yöneticilerinde Algıladıkları Dönüşümcü Liderlik Davranışının Psikolojik Sermaye ve İş Performansı Düzeyleri Üzerindeki Etkisi: İstanbul Örneği, (Editör) Erdoğan, T., Temizer, A. ve İnan, R.: Sosyal Bilimlerde Akademik Çalışmalar içinde (ss.763-786) Montenegro: Ivpe Cetinje. 
Crawshaw, J.R., van Dick, R., and Brodbeck, F.C. (2012). Opportunity, Fair Process and Relationship Value: Career Development as a Driver of Proactive Work Behaviour, Human Resource Management Journal, 22(1): 4-20.

Çelik, S., Dedeoğlu, B.B. and İnanır, A. (2015). Relationship Between Ethical Leadership, Organizational Commitment and Job Satisfaction at Hotel Organizations, Ege Akademik Bakış, 15(1):53-63.

Çöl, G. (2008). Algılanan Güçlendirmenin İşgören Performansı Üzerine Etkileri, Doğuş Üniversitesi Dergisi, 9 (1): 35-46.

Çöp, S. ve Doğanay, A. (2020). Algılanan Liderlik İletişiminin İş Performansı ve İş Tatminine Etkisi: 4 ve 5 Yıldızlı Otel Çalışanları Üzerine Bir Araştırma, İstanbul Gelişim Üniversitesi Sosyal Bilimler Dergisi, 7(1): 34-49.

Dau-Schmidt, K.G. and Ray, M.D. (2004), The Definition of "Employee" in American Labor and Employment Law, in Japanese Institute for Labor and Policy Training, Comparative Labor Law Seminar, 3: 117-124.

Demirel, Z.H. (2017). Yöneticilerin Liderlik Davranışlarının İşgören Performansı ile İlişkilerin İncelenmesi: Beş Yıldızlı Otel İşletmelerinde Bir Uygulama, Akademik Bakış Dergisi, 62: 381-397.

Dhar, R.L. (2016). Ethical Leadership and Its Impact on Service Innovative Behavior: The role of LMX and Job Autonomy, Tourism Management, 57: 139-148.

Doğan, S. ve Dülger E. (2020). Turizm İşletmelerinde Kariyerizm, (Editör) Ercan İştin, A. ve Çelik, S.: Turizm İşletmelerinde Negatif Örgütsel Davranışlar 2 içinde (ss.67-79) Ankara: Detay Yayıncılık.

Durgut, A.İ. (2020). Etik Liderlik, İşe Adanmışlık ve Yönetsel Yaratıcılık Arasındaki İlişki: Yapı Malzemeleri Sektöründe Bir Uygulama, Yayınlanmamış Yüksek Lisans Tezi, Trakya Üniversitesi, Edirne.

Eisenberger, R., Huntington, R., Hutchison, S., and Sowa, D. (1986). Perceived Organisational Support, Journal of Applied Psychology, 71(3): 500-507.

Enderle, G. (1987). Some Perspectives of Managerial Ethical Leadership, Journal of Business Ethics, 6(8): 657-663.

Erdilek Karabay, M. (2002). İşletmelerde Etik ve Etik Liderlik. İstanbul: BETA Yayıncıllk.

Erol, S., Göktaş Kulualp, H. (2019). Etik Liderlik Davranışının Bazı Değişkenler Açısından İncelenmesi, Karabük Üniversitesi Sosyal Bilimler Enstitüsü Dergisi, 9 (2): 696-705.

Eşitti, B. (2019). Restoran İşletmelerinde Etik Liderlik ve Örgütsel Bağlllık: Servis İkliminin Rolü, Trakya Üniversitesi Sosyal Bilimler Dergisi, 21: 43-64.

Feldman, D.C. and Weitz, B.A. (1991). From The Invisible Hand to The Gladhand: Understanding A Careerist Orientation to Work, Human Resource Management, 30(2): 237-257.

Ghalem, Â., Okar, C., Chroqui, R. and Semma, E. (2016), Performance: A Concept to Define. [Çevrimiçi] https://doi.org/10.13140/rg.2.2.24800.28165> [Erişim Tarihi: 21.02.2021].

Girdap, E. (2019). Kariyerizm ile İş-Yaşam Dengesi Arasındaki İlişki Üzerine Bir Araştırma, Yayınlanmamış Yüksek Lisans Tezi, Sakarya Üniversitesi, Sakarya.

Girdap, E., Giden, B. ve Özdemir, Y. (2019). Y Kuşağının Kariyerizm Algısının İncelenmesi Üzerine Bir Araştırma, 1. Ulusal Safranbolu Girişimcilik ve Sosyal Bilimler Öğgrenci Kongresi, Karabük Üniversitesi 18-19 Nisan 2019. Karabük. ss: 59-67. 
Hall, D. T. (1976). Careers in Organizations. Glenview, IL: Scott, Foresman.

Hamilton, S. M. and Treuer, K. V. (2012). An Examination of Psychological Contracts, Careerism and ITL. Career Development International, 17(5): 475-494

Hsiung, H. H., Lin, C. W. and Lin, C. S. (2012). Nourishing or Suppressing? The Contradictory İnfluences of Perception of Organizational Politics on Organizational Citizenship Behaviour, Journal of Occupational and Organizational Psychology, 85(2): 258-276.

Jain, A. K. and Sullivan, S. (2020). An Examination of The Relationship Between Careerism and Organizational Commitment, Satisfaction, and Performance. Personnel Review, 49: 1553-1571.

Kalyar, M.N., Shafique, I. and Ahmad, B. (2019), Job Stress and Performance Nexus in Tourism Industry: A Moderation Analysis, Tourism: An International Interdisciplinary Journal, 67(1): 6 - 21.

Kanungo, R.N. (2001). Ethical Values of Transactional and Transformational Leaders, Canadian Journal of Administrative Sciences, 18(4): 257-265.

Karatepe, O.M. (2013), High-Performance Work Practices and Hotel Employee Performance: The Mediation of Work Engagement, International Journal of Hospitality Management, 32: 132-140.

Karatepe, O.M., Uludağ, O., Meneviş, İ., Hadzimehmedagic, L. and Baddar, L. (2006), The Effects of Selected Individual Characteristics on Frontline Employee Performance and Job Satisfaction, Tourism Management, 27: 547-560.

Kesen, M. (2016). Öğretim Elemanlarının İşe Yabancılaşmasının Etik Liderlik ve Demografik Değişkenler Açısından İncelenmesi: Uygulamalı Bir Çalışma, Akademik Sosyal Araştırmalar Dergisi, 22: 118-134.

Khokhar, A.M. and Zia-ur-Rehman, M. (2017). Linking Ethical Leadership to Employees' Performance: Mediating Role of Organizational Citizenship Behavior and Counterproductive Work Behavior, Pakistan Journal of Commerce and Social Sciences, 11(1): 222-251.

Khuntia, R. and Suar, D. (2004). A Scale to Assess Ethical Leadership for Indian Private and Public Sector Managers, Journal of Business Ethics, 49: 13-26.

Khuong, M.N. and Nhu, N.V.Q. (2015). The Effects of Ethical Leadership and Organizational Culture Towards Employees' Sociability and Commitment-A Study of Tourism Sector in Ho Chi Minh City, Vietnam, Journal of Advanced Management Science, 3(4): 329-336.

Khuong, M.N., and Quoc, T.H. (2016). The Effects of Organizational Justice and Ethical Leadership on Employee Performance in Binh Duong's Industrial Parks, Vietnam, Journal of Economics, Business and Management, 4(4): 327-333.

Kim, H., Kang, D., Lee, S. and McLean, G. (2016). Career Commitment as A Mediator Between Organization-Related Variables and Motivation for Training and Turnover İntentions, Journal of Career Development, 43(2): 130-144.

Kirkman, B. L. and Rosen, B. (1999). Beyond Self-Management: Antecedents and Consequences of Team Empowerment, Academy of Management Journal, 42(1): 58-74.

Kocaman, G. (2017). İşgören Performansı ve İşgören Memnuniyetinin İşletme Performansına Etkisi: Turizm Sektöründe Bir Uygulama, The International New Issues in Social Sciences, 4(4): 6576.

Lebas, M.J. (1995). Performance Measurement and Performance Management, International Journal of Production Economics, 41(1-3): 23-35. 
Liman, A., Elçi, M. ve Murat, G. (2019). Örgütsel Performansın Öncülleri Olarak Etik Liderlik ve Kariyerizm Üzerine Bir Araştırma, Uluslararası Ekonomi, İşletme ve Politika Dergisi, 3(2): 183-198.

Mayer, D.M., Aquino, K., Greenbaum and R.L., Kuenzi, M. (2012). Who Displays Ethical Leadership, and Why Does it Matter? An Examination of Antecedents and Consequences of Ethical Leadership, Academy of Management Journal, 55(1): 151-171.

Millerd, P. (2020). The Knowledge Worker Mind and The Birth of Careerism, https://thinkboundless.com/careerism-performers/> [Erişim Tarihi: 26.06.2021]

Muhl, C.J. (2002), What Is An Employee?, Monthly Labor Review, 125(1): 3-11.

Nguyen, T. and Luu, T. (2019). How Ethical Leadership Supports Employee Performance: The Role of Psychological Capital and Employee Engagement, The Journal of Social Sciences Research, 5(11): 1637-1648.

Nicolaides, A. (2019). Ethical Leadership in A Morally Driven Hospitality Organisational Culture, African Journal of Hospitality, Tourism and Leisure, 8(5): 1-14.

Nişanyan Etimoloji Sözlüğü, NES. (2021). "Etik" kelimesi https://www.nisanyansozluk.com/?k=Etik> [Erişim Tarihi: 24.01.2021].

Özdemir, Y. ve Üzüm, B. (2019). Yengeç Sendromu, (Editör) Kaygın, E. ve Kosa, G.: Olumsuz Boyutlarıyla Örgütsel Davranış içinde (ss. 125-138). Konya: Eğitim Yayınevi.

Özer, E. (2019). Yiyecek İçecek Bölümü Çalışanlarının İş Performansı ve İşten Ayrılma Niyetlerine İlişkin Algı Düzeylerinin Belirlenmesi: Afyonkarahisar Örneği. Journal of Tourism and Gastronomy Studies, 7 (2): 1012-1034.

Peiperl, M. and Baruch, Y. (1997). Back To Square Zero: The Post-Corporate Career, Organizational Dynamics, 25(4): 7-22.

Rubinstein, M.H. (2012), Employees, Employers, and Quasi-Employers: An Analysis of Employees and Employers Who Operate in The Borderland Between an Employer and Employee Relationship, University of Pennsylvania Journal of Business Law, 14(3): 605-659.

Samsonowa, T. (2012). Industrial Research Performance Management - Key Performance Indicators in the ICT Industry. Heidelberg: Springer-Verlag.

Skopec, R. (2019). Darwin's Theorem Revised: Survival of the Careerist, Advancements in Cardiology Research and Reports, 1(5): 99-104.

Seçer, B. ve Çınar, E. (2011). Bireycilik ve Yeni Kariyer Yönelimleri, Yönetim ve Ekonomi Dergisi, 18(2): 49-62.

Shafique, I., Kalyar, M.N. and Ahmad B. (2018). The Nexus of Ethical Leadership, Job Performance, and Turnover Intention: The Mediating Role of Job Satisfaction, Interdisciplinary Description of Complex Systems, 16(1): 71-87.

Sigler, T.H., Pearson and C. M. (2000). Creating an Empowering Culture: Examining The Relationship Between Organizational Culture and Perceptions of Empowerment, Journal of Quality Management, 5: 27-52.

Sverke, M., Låstad, L., Hellgren, J., Richter, A. and Näswall, K. (2019). A Meta-Analysis of Job Insecurity and Employee Performance: Testing Temporal Aspects, Rating Source, Welfare Regime, and Union Density as Moderators, International Journal of Environmental Research and Public Health, 16: 1-29. 
Şengüllendi, M.F., Şehitoğlu, Y. ve Kurt, E. (2020). Toksik Liderlik ve Üretkenlik Karşıtı İş Davranışları İlişkisinde Kariyerizmin Aracı Etkisi, KAÜiİBFD, 11(22): 743-765.

Şentürk, F.K., Boğan, E. ve Bayırlı, M. (2019). Etik Liderlik ve Materyalist Eğilimlerin Otel Çalışanlarının Kurumsal Sosyal Sorumluluk Algısına Etkisi: Alanya Örneği, Seyahat ve Otel İşletmeciliği Dergisi, 16(1): 136-153.

Tekin, E. (2018). Lider-Üye Etkileşiminin Çalışan Performansı Üzerindeki Etkisinde Örgütsel Vatandaşlık Davranışının Aracı Rolü, Karadeniz Teknik Üniversitesi Sosyal Bilimler Enstitüsü Sosyal Bilimler Dergisi, 8(16): 343-363.

Tekingündüz, S., Kurtuldu, A. ve Eğilmez, Ç. (2016). Sosyal Destek, İşe Yabancılaşma ve İş Stresinin İşgören Performansı Üzerindeki Etkisinin İncelenmesi, International Journal of Human Sciences, 13(1): 683-694.

Tewksbury, R. (2009). Qualitative Versus Quantitative Methods: Understanding Why Qualitative Methods Are Superior for Criminology and Criminal Justice, Journal of Theoretical and Philosophical Criminology, 1(1): 38-58.

Tuna, M., Bircan, H. ve Yeşiltaş, M. (2012). Etik Liderlik Ölçeğinin Geçerlilik ve Güvenilirlik Çalışması: Antalya Örneği, Atatürk Üniversitesi İktisadi ve İdari Bilimler Dergisi, 26(2): 143-155.

Turan, H.Y. ve Cinnioğlu, H. (2020). Otel İşletmeleri Çalışanlarının Algıladıkları Liderlik Tarzının Performans Düzeyine Etkisi: Antalya Örneği, İstanbul Ticaret Üniversitesi Sosyal Bilimler Dergisi, 19(39): 1227-1245.

Türk Dil Kurumu, TDK. (2021). “Etik” kelimesi https://sozluk.gov.tr/> [Erişim Tarihi: 24.01.2021].

Türk Dil Kurumu, TDK (2020). “Performans" kelimesi https://sozluk.gov.tr/> [Erişim Tarihi: 15.01.2021].

Ural, A. ve Kılıç, İ. (2013). Bilimsel Araştırma Süreci ve SPSS ile Veri Analizi. (4. Baskı), Ankara: Detay Yayıncilık.

Üzüm, B. (2018). Kariyerizm Bir Davranış Eğilimi Olarak Negatif Midir? Pozitif Midir?, Social Sciences Studies Journal, 4(25): 5351-5354.

Whyte, W.H. (1956). The Organization Man. (2002 Bask1sı), Pennsylvania: University of Pennsylvania Press.

Whitaker, B. (2011). Extreme Careerism and Supervisor Reactions to Peer Intimidation, Academy of Management Proceedings, https://journals.aom.org/doi/pdf/10.5465/ambpp.2011.65870181> [Erişim Tarihi: 26.06.2021]

Yeşiltaş, M., Çeken, H. ve Sormaz, Ü. (2012). Etik Liderlik ve Örgütsel Adaletin Örgütsel Sapma Davranışları Üzerindeki Etkisi, Muğla Üniversitesi Sosyal Bilimler Enstitüsü Dergisi, 28: 18-39.

Yıldız, B. (2015). The Antecedents of Constructive and Destructive Deviant Workplace Behaviors, Yayınlanmamış Doktora Tezi, Gebze Teknik Üniversitesi, Kocaeli.

Yıldız, B. (2016). Kariyerizm ile Zorunlu Vatandaşlık Davranışları Arasındaki İlişkide İşten Ayrılma Niyetinin Moderator Etkisi, 24. Ulusal Yönetim ve Organizasyon Kongresi, Sabanc1 Üniversitesi 29-31 Mayıs 2016. İstanbul. ss: 196-203.

Yıldız, B. ve Ayaz Arda, Ö. (2018). İyi Bir Asker Mi? İyi Bir İllüzyonist Mi? Kariyerizm ile Zorunlu Vatandaşlık Davranışları Arasındaki İlişkide İşten Ayrılma Niyetinin Rolü, Business and Economics Research Journal, 9(1): 151-167. 
Yıldız, B., Yıldız, H. ve Alpkan, L. (2015). Olağandışı İşyeri Davranışlarının Bir Öncülü Olarak Kariyerizm. 3. Örgütsel Davranış Kongresi, İstanbul Üniversitesi 6-7 Kasım 2015. Tokat. ss: 684-689.

Yılmaz, H. ve Karahan, A. (2010). Liderlik Davranışı, Örgütsel Yaratıcılık ve İşgören Performansı Arasındaki İlişkilerin İncelenmesi: Uşak'ta Bir Araştırma, Yönetim ve Ekonomi, 17(2): 145-158.

Yozgat, U., Yurtkoru, S. and Bilginoğlu, E. (2013). Job Stress and Job Performance Among Employees in Public Sector in Istanbul: Examining the Moderating Role of Emotional Intelligence, Social and Behavioral Sciences, 75: 518-524.

Zehir, C., Erdal, N., Sivaslığlu, F. and Demir, B. (2019). Mediating Role of Relationship Orientation on Ethical Leadership and Employee Performance Relation. Joint Conference of 14th International Strategic Management Conference (ISMC) and 8th International Conference on Leadership, Technology, Innovation and Business (ICLTIBM), 12 - 14 July 2018, Prague, Czech Republic.

Zhu, Y., Sun, L., and Leung, A.S.M. (2014). Corporate Social Responsibility, Firm Reputation, and Firm Performance: The Role of Ethical Leadership, Asia Pac J Manag, 31: 925-947.

Zulhelmi, Z., Muchtar, B., and Abror, A. (2019). The Impact of Innovative Behavior, Commitment, Organizational Culture, and Ethical Leadership on Performance, Advances in Economics, Business and Management Research, 64: 846-855. 